относительно подготовки военных специалистов к выполнению ими должностных обязанностей на первичных должностях, приведение уровня их профессиональной подготовки в соответствии с нормативно правовыли актами и требованиями военно-профессиональной деятельности.

Ключевые слова: формы и методы обучения, инновачионные технологии обучения, учебный процесс, операционные карты, учебные задания.

\title{
ORGANIZATION OF LEARNING PROCESS FOR CADETS IN MILITARY EDUCATIONAL INSTITUTIONS IN ACCORDANCE WITH PRINCIPLES OF SYSTEMATIC AND PHASED IMPLANTING OF KNOWLEDGE AND SKILLS
}

S.V. Bokachov, I.V. Babirad, V.S. Gluschenko

Organization of learning process in military educational institutions, that takes into consideration principles of systematic and phased implanting of knowledge and skills, in order to enhance the effectiveness of learning, accomplish tasks of Ukrainian Armed Forces, which concern preparing military specialists for performing post responsibilities on their initial positions, bring the level of their professional training in accordance with regulatory and legal acts and requirements of military professional work has been examined.

Keywords: forms and methods of teaching, innovative teaching technologies, learning process, operational maps, task for learning.

\section{УДК 623.592}

\author{
Я.В. Красник, О.В. Римар, С.А. Мартиненко
}

Академія сухопутних військ імені гетьмана Петра Сагайдачного, Львів

\section{ПРИНЦИПИ ПОБУДОВИ ПЕРСПЕКТИВНИХ НАВЧАЛЬНО-ТРЕНУВАЛЬНИХ ЗАСОБІВ ДЛЯ ПІДГОТОВКИ ЕКІПАЖІВ БОЙОВИХ МАШИН, ПІДРОЗДІЛІВ (ЧАСТИН, З'ЄДНАНЬ), ЛАНОК УПРАВЛІННЯ РАКЕТНИХ ВІЙСЬК І АРТИЛЕРІЇ СУХОПУТНИХ ВІЙСЬК}

Вирішення проблеми низької ефективності навчально-тренувальних засобів ракетних військ $i$ артилерї Сухопутних військ потребує створення ефективних навчально-тренувальних засобів для підготовки екіпажів бойових машин, підрозділів (частин, з’єднань), ланок управління ракетних військ $i$ артилерії, які в подальшому будуть об'єднані в тренажно-моделювальні комплекси $i$ системи. Запропоновані в статті принщипи побудови навчально-тренувальних засобів являють собою ряд конкретних пропозищій щзодо створення перспективних навчально-тренувальних засобів для підготовки екіпажів бойових машин, підрозділів (частин, з'єднань), ланок управління ракетних військ $і$ артилерії Сухопутних військ. Результати можуть бути використані в інтересах ракетних військ $i$ артилерії Сухопутних військ в ході виконання дослідних $і$ дослідно-конструкторських робіт щзодо відпраџювання технічних завдань для модернізаці і створення навчально-тренувальних засобів, планування їх використання в навчальному процесі, а також для створення перспективних навчально-тренувальних засобів інших родів військ Сухопутних військ.

Ключові слова: ракетні війська і артилерія, навчально-тренувальні засоби, тренажно-моделювальний комплекс, тренажно-моделювальна система, тренажер.

\section{Вступ}

Постановка проблеми. Навіть найефективніші навчально-тренувальні засоби (НТ3) на сьогод-

нішній час не можуть повною мірою замінити заняття в польових умовах з залученням озброєння i військової техніки (ОВТ).

Як недолік використання НТЗ РВіА (особливо для проведення бойового злагодження в складі підрозділів, частин, угрупувань ракетних військ і артилерії (РВiA) і РВіА Сухопутних військ (СВ) в цілому, штабних тренувань (ШТ), командноштабних навчань (КШН) 3 використанням тренажно-моделювальних систем (ТМС) РВіА) $є$ те, що процес інтенсифікації навчального процесу (перш за все зменшення часу виконання завдань на засобах тренажно-моделювальних комплексів (ТМК) в порівнянні з реальними діями військ) не дає змоги в повному обсязі враховувати вплив процесів забезпечення життєдіяльності людини (фізіологічних процесів в організмі і процесів 
забезпечення особистих потреб - відпочинок (в т.ч. сон), харчування, вмивання, фізичні вправи, перегляд преси, телепередач, природні потреби і т.п.), які проходять в реальному масштабі часу, а також чинників зовнішнього середовища (пора року, час доби, погодні умови і т.п.) на хід і результат виконання поставлених завдань.

Вплив морально-психологічного i фізичного стану людини (в т.ч. військовослужбовців), фізіологічних процесів в організмі на іiі діяльність (отримання ними вмінь і навиків) досить значна i повинна враховуватись в процесі навчання 3 застосуванням НТЗ. Цей вплив посилюється в найбільш складних і напружених ситуаціях.

Тому основою тренажерної бази РВіА повинна стати комплексна ТМС PBiA СВ. Структурно ТМС включає комп'ютерні засоби навчання з відповідним спеціальним програмним i математичним забезпеченням (СПМЗ), комплексні тренажери різних типів ОВТ, полігонне обладнання, імітаційні та вимірювальні засоби, навчально-тренувальні ракетні, артилерійські, розвідувально-артилерійські системи.

Перспективні НТ3 для підготовки екіпажів бойових машин, підрозділів (частин, з'єднань), ланок управління РВіА, як складова ТМС, будуть включати:

- комп’ютерні засоби навчання;

- комп'ютерно-орієнтоване

методичне забезпечення.

Виходячи з вищесказаного слід відмітити, що найбільшу ефективність будуть мати ті елементи заняття (навчання), які мають відповідне комп'ютерно-орієнтоване методичне забезпечення і проводяться в реальному масштабі часу. Оскільки це входить в протиріччя 3 необхідністю інтенсифікації навчання (щодо зменшення часу проведення), то при підготовці занять (навчань) слід відпрацьовувати часовий сітьовий графік їх проведення, в якому вплив оперативних стрибків на достовірність обстановки i дій буде мінімізовано.

\section{Аналіз останніх досліджень i} публікацій. Основні концепції, напрямки і проблеми розвитку НТ3 в Збройних Силах України знайшли своє висвітлення в газетах і журналах, фахових виданнях Міністерства оборони («Наука і оборона», «Народна армія», «Військо України», труди академії Збройних Сил України (національної академії оборони України) і ін.), науково-дослідних роботах наукового центр СВ (м. Львів) [1], Наукового центру артилерії (м. Суми) [2]. Дослідниками розвитку НТ3 (Руснак I.C., Факадей Р.М., Шевченко В.Л., Пригунов О.П., Зінченко Ю.М., Чопа Д.А., Артемов Ю.І. і ін.) починаючи з 1997 року створена необхідна теоретична база основ розвитку перспективних НТ3 в Збройних Силах України.

Метою статті $\epsilon$ надання пропозицій щодо створення перспективних НТЗ РВіА Сухопутних військ для підготовки екіпажів бойових машин, підрозділів (частин, з'єднань), ланок управління ракетних військ і артилерії.

\section{Основний матеріал}

Розглядаючи принципи побудови перспективних НТ3 для підготовки екіпажів бойових машин, підрозділів (частин, з'єднань), ланок управління $\mathrm{PBiA} \mathrm{CB}$ необхідно перш за все враховувати принципи побудови ТМС РВіА [1]:

- повна аналогія органів управління реальним зразкам, відтворення процесів та дій за типом реальних зразків озброєння та техніки;

- імітація обстановки бою в максимально повному обсязі;

- створення умов для найбільшої кількості навчаємих;

- безпека застосування під час занять;

- дохідливість та наочність навчання (тренування);

- об'єктивна оцінка всіх посадових осіб та підрозділів у відповідності до курсів підготовки РВіА;

- мінімальні матеріальні витрати;

- максимальне використання штатного озброєння та військової техніки;

- конструктивне виконання комплексу «3 відкритою архітектурою»;

- інтеграція 3 іншими тренажними системами видів, родів військ Збройних сил України в єдину тренажну систему.

\section{Комп'ютерні засоби навчання}

Комп'ютерні засоби навчання екіпажів (бойових розрахунків) бойових машин (ланок управління) розглянемо за наступними, взаємозв'язаними між собою, групами:

- засоби технічної підготовки - навчальні комп'ютерні програми, відеофільми, навчальнодіючі стенди;

- засоби індивідуальної бойової підготовки членів екіпажу (бойового розрахунку) - тренажери різноманітного ступеню складності (настільні, статичні, динамічні);

- засоби відпрацювання взаємодії всередині екіпажу (бойового розрахунку) бойової машини (ланки управління) - об'єднання засобів індивідуальної бойової підготовки членів екіпажу (бойового розрахунку) в тренажер екіпажу (бойового розрахунку) бойової машини (ланки управління); 
- засоби відпрацювання тактичної взаємодії екіпажів (бойових розрахунків) бойових машин (ланок управління) в складі підрозділу (частини, 3'єднання) - об'єднання тренажерів екіпажів (бойових розрахунків) в єдину мережу для сумісних дій на віртуальному полігоні;

- засоби відпрацювання тактичної взаємодії підрозділів (частин, з’єднань) для сумісних дій на єдиному віртуальному полігоні;

- засоби відпрацювання оперативностратегічної взаємодії з іншими родами військ.

\section{Засоби технічної підготовки}

До засобів технічної підготовки відносяться навчальні комп'ютерні програми, відеофільми, навчально-діючі стенди.

Навчальні комп'ютерні програми, побудовані на принципах двохмірної анімації, ефективні як при індивідуальному навчанні в комп'ютерних класах, так і при груповому навчанні в процесі проведення лекцій. Анімоване зображення наглядно демонструє принцип роботи систем бойових машин, моделюючи їх роботу.

Навчальні комп'ютерні програми, побудовані на принципах трьохмірної анімації, а також відеофільми дають теоретичні знання щодо будови і технічного обслуговування агрегатів і систем бойових машин.

Практичні навички щодо технічного обслуговування агрегатів і систем бойових машин військовослужбовці (курсанти) можуть отримати на навчально-діючих стендах, де агрегати і системи, що вивчаються, відтворені в реальному масштабі.

\section{Засоби індивідуальної бойової підготовки членів екіпажу}

До засобів індивідуальної бойової підготовки членів екіпажу відносяться тренажери різноманітного ступеню складності: динамічні, статичні і настільні. Найбільш ефективним засобом індивідуальної бойової підготовки являються динамічні тренажери, а статичні і настільні тренажери являють собою прості i дешеві їx модифікації. Вони призначені для прищеплення навичок роботи з окремими приборами (наприклад, прицілами) - в настільному варіанті, або для закріплення сенсомоторних навичок - в варіанті статичного тренажера.

Динамічні тренажери членів екіпажів бойових машин будуються за єдиним принципом і повинні складатися з наступних основних компонентів:

- кабіна з робочим місцем члена екіпажу;

- робоче місце інструктора;

- система візуалізації;

- динамічна платформа з системою управління;

- програмне забезпечення 3 математичними моделями.

\section{Кабіна з робочим місцем члена екіпажу}

Прилади спостереження і прицілювання, пульти i органи управління тренажера повинні повністю відповідати реальному об'єкту і бути зв'язаними 3 математичними моделями бойових машин через пристрої сполучення, які бувають розподіленого і унітарного типу.

Розподілений тип пристрою сполучення являє собою набір процесорних блоків, які оснащені необхідною кількістю аналогових i дискретних входів i виходів. Кожний процесорний блок вбудовується індивідуально в приціл, пульт і інші пристрої і з'єднується в єдину мережу з іншими блоками.

Цей варіант має добрі показники, однако дорожчий за варіант унітарного виконання. Унітарний пристрій сполучення являє собою єдиний процесорний блок 3 необхідною кількістю аналогових і дискретних входів і виходів, до якого стікаються всі сигнали від усіх пристроїв, що розміщені на робочому місці члена екіпажу. Унітарний пристрій сполучення може бути як зовнішнім, так і вмонтованим.

Зовнішній пристрій сполучення прийнятно для статичних i настільних тренажерів. Він може розміщатися поза кабіною. Для динамічних тренажерів зовнішній пристрій неприйнятний через низьку надійність рухомого стику кабеля при великій кількості сигналів.

Найбільш привабливим, виходячи із вартості, якості i надійності, $€$ вмонтований унітарний пристрій сполучення. Такий пристрій сполучення встановлюється всередині кабіни і з'єднується 3 електронно-обчислювальною машиною (ЕОM), яка виконує розрахунок моделей руху виробу, що забезпечує більшу надійність.

Робоче місце інструктора. На робочому місці інструктора (викладача) необхідно задавати початкові умови: погода, час року, час доби, а також контролювати послідовність i правильність дій навчаємого за сигналами, що відображаються на моніторі. Програмне забезпечення на EOM, що забезпечує роботу робочого місця інструктора, повинно дозволити проконтролювати дії навчаємого 3 наступним відтворенням i роздруківкою екзаменаційного листка.

Для контролю дій навчаємого в кабіні тренажера може встановлюватися камера відеонадзору, монітор якої виводиться на робоче місце інструктора.

Система візуалізації. Система візуалізації повинна відображати достовірні трьохмірні моделі місцевості, побудовані на основі реальних цифрових карт, з відображенням деталей, таких як текстури поверхні, камені, трава, чагарники, дерева, споруди. 
Візуалізація дозволяє вміщати на місцевості велику кількість типів цілей, віртуальний зовнішній вигляд і габарити яких відповідають реальним прототипам. Система візуалізації повинна забезпечити відображення погодних умов (дощ, сніг, туман), зовнішніх умов, що відповідають часу року, часу доби.

Моделювання візуального зображення бойової обстановки - одна 3 найскладніших проблем процесу комп'ютеризації НТЗ. Однако це найефективніший засіб забезпечення подібності штучного середовища (середовища бойової діяльності, імітованого на тренажері) реальному середовищу.

Оснащення тренажерів візуально-проекційною системою (ВПС) дозволяє повною мірою реалізувати принцип наочності навчання, якій базується на відомій закономірності пізнання, згідно 3 якою зоровий канал людини має найбільшу перепускну спроможність при сприйманні процесів і явищ порівняно 3 іншими способами. Передача інформації на основі зорового сприймання осіб, що навчаються, дозволяє за той самий час передати більший за обсягом навчальний матеріал, ніж за іншими способами та максимально наблизити умови навчання до реальних [3].

Найефективнішими є тренажери, які імітують візуальну інформацію з круговим оглядом, а також тренажери, виконані за технологією «віртуальної реальності» [4]. Але, при всіх їх перевагах, вони є самими дорогими та на думку фахівців провідних в воєнному відношенні держав такі тренажери повинні застосовуватися перш за все при підготовці окремих фахівців, а саме: екіпажів літаків, вертольотів, навідників танків, гармат, операторів зенітних переносних ракетних комплексів, протитанкових ракетних комплексів (ПТРК), тощо.

3 урахуванням завдань, які вирішуються артилерією, на теперішній час найбільш прийнятними способами доведення візуальної інформації в умовах ТМК слід вважати оснащення тренажерних модулів (ТМ) (навчальних місць) проекційними екранами, або монтаж пристроїв доведення візуальної інформації безпосередньо на засоби спостереження (оптичної розвідки) або ТМ. Прикладом такого технічного рішення є розробки чеської фірми «Е-СОМ», яка поставляе тренажерне обладнання для підготовки фахівців артилерії. На рис. 1 наведений ТМ підготовки операторів та водіїв ПТРК, де засобом доведення зорової інформації є проекційний екран.

Доведення зорової інформації до командира та навідника TM 152мм пушки-гаубиці «Дана» здійснюється за допомогою моніторів, які змонтовані безпосередньо на ТМ (рис. 2).

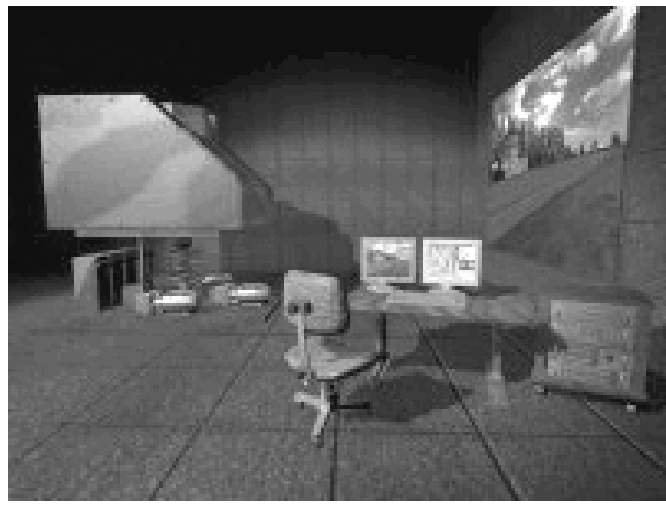

Рuc. 1. ТМ підготовки операторів та водіїв ПТРК чеського виробництва

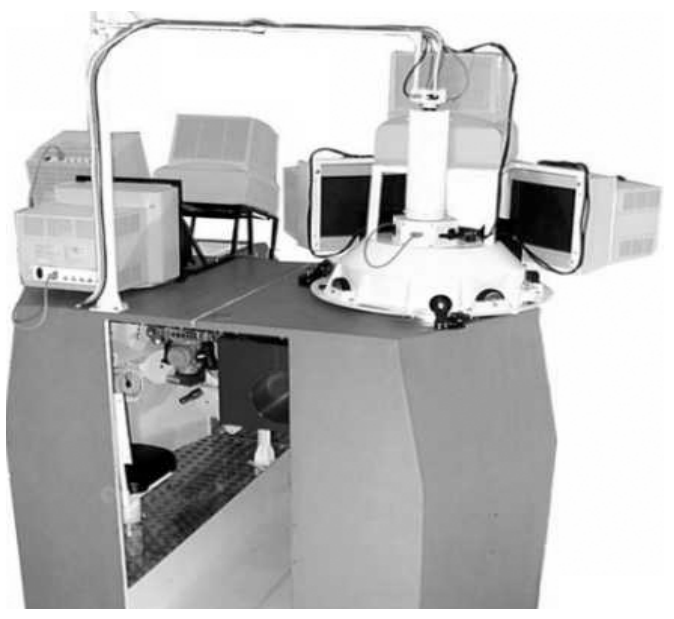

Рис. 2. ТМ підготовки обслуги 152 мм пушки-гаубиці «Дана» чеського виробництва

Процес моделювання візуального зображення бойової обстановки в умовах ТМК буде містити в собі декілька етапів та залежати, головним чином, від обраної форми навчання, теми заняття та навчальних питань, які планується відпрацювати в його ході, рівня навченості тих, хто залучається на заняття, та здійснюватися в декілька етапів.

Такими етапами є:

- формування базового пейзажу та умов спостереження;

- насиченість базового пейзажу ознаками діяльності військ;

- моделювання бойових дій 3 відображенням очікуваних результатів на основі прийнятого рішення.

Якщо перші два етапи будуть властиві практично всім формам навчання, то останній етап буде притаманний таким формам навчання як ШТ та КШН на засобах ТМК. Тобто там, де прийняті рішення здійснюють відповідний вплив на візуальне відображення обстановки та подальший хід заняття в цілому. 
Формування базового пейзажу та умов спостереження повинно здійснюватися програмно за участю керівника заняття. Сутність формування базового пейзажу та умов спостереження полягає в тому що керівник заняття за допомогою зручного інтерфейсу, 3 урахуванням тематики заняття, визначає основні чинники, які характеризують район бойових дій та умови спостереження. В подальшому, на основі вказаних керівником даних, програмно 3 бази даних формується та висвітлюється на екрані (екранах) ВПС ТМ (навчальних місць) відповідне зображення місцевості. 3 урахуванням того, що отримана інформація в подальшому може відображатися на робочих картах, базові пейзажі повинні формуватися на картографічній основі.

До чинників, які характеризують район бойових дій та умови спостереження, слід віднести:

- розміри району бойових дій;

- тип місцевості;

- погодно-кліматичні умови, час доби, пора року;

- характер протидії противника.

При проведенні тренувальних, комплексних (контрольно-комплексних) занять 3 батареєю, виконанні вогневих завдань на засобах ТМК розміри району бойових дій будуть визначатися фронтом та глибиною перспективного зображення ділянки місцевості (ПЗДМ) на екрані ВПС ТМ та складати до 3км по фронту та до 5км в глибину. Фронт та глибина ПЗДМ будуть обумовлені шириною та глибиною смуги, в межах якої ведеться оптична розвідка відділенням управління та фізіологічними можливостями людини отримувати зорову інформацію неозброєними оком. Крім того такими розмірами ПЗДМ забезпечиться можливість отримання тими, хто навчається, необхідної зорової інформації для відпрацювання питань топогеодезичної прив'язки, підготовки навігаційної апаратури, організації та ведення оптичної розвідки 3 командно-спостережного (спостережного) пункту, проведення рекогносцировки, організації взаємодії на місцевості, виконання вогневих задач та інших.

Розміри району бойових дій при проведенні КШН на засобах ТМК повинні визначатися фронтом та глибиною бойової задачі загальновійськової частини (підрозділу) в складі якого діє БрАГ (артилерійський дивізіон). 3 урахуванням того, що БрАГ входить до складу механізованої бригади, а артилерійський дивізіон може додаватися (підтримувати дії) механізованого батальйону, розміри району бойових дій при проведенні КШН на засобах ТМК з БрАГ повинні складати в середньому за фронтом до 15км та до 20км в глибину а при проведенні КШН на засобах ТМК з артилерійським дивізіоном за фронтом до 5км та до 10км в глибину. Тобто виникає необхідність розробки СПМЗ, яке б забезпечувало в межах визначеного району бойових дій (на картографічній основі) формування на екрані ВПС ТМ перспективного зображення ділянки місцевості, що буде спостерігатися з місця розміщення ТМ в цьому районі. Вихідними даними для формування ПЗДМ можуть бути координати ТМ та напрямок (кут) в якому ведеться спостереження або розвідка. Виходячи з чинників, які наведені вище, фронт та глибина ПЗДМ на екрані ВПС ТМ будуть складати до 3 км та до 5 км відповідно.

Тип місцевості визначається такими загальновідомими властивостями як умови спостереження, рельєф, характер грунтово-рослинного покриття, ступінь пересіченості [5]. В умовах ТМК при формуванні зображення місцевості необхідно враховувати специфіку навчальних питань, які планується відпрацювати на занятті 3 метою забезпечити тих, хто навчається, всією вихідною інформацією, яка може бути отримана на місцевості. Тому крім характеристик наведених вище, місцевість додатково повинна характеризува-тися за ознаками, які визначають можливість відпрацювання саме цих питань. Такими ознаками є, наприклад, насиченість місцевості топогеодезичною мережею (контурними точками), ширина водної перешкоди тощо.

Врахування погодно-кліматичних умов, часу доби дозволить керівникові заняття впливати на хід заняття через природні явища. До таких явищ слід віднести дощ, сніг, туман, хмарність, сутінки, ніч тощо. Можливість врахування цих явищ буде спонукати тих хто навчається приймати відповідні рішення. Наприклад:

- погіршення умов спостереження (дощ, сніг, туман) - застосування засобів розвідки;

- хмарність - застосування високоточних боєприпасів;

- ніч - виконання завдань світового забезпечення та інші.

На етапі формування базового пейзажу та умов спостереження характер протидії противника слід розглядати 3 точки зору його впливу на умови спостереження. Ознаками впливу може бути імітація короткочасного або тривалого погіршення умов спостереження внаслідок застосування противником димових завіс, пил від вибухів, засліплення приладів спостереження, застосування зброї масового ураження.

Насиченість базового пейзажу ознаками діяльності військ повинно здійснюватися шляхом доведення до тих, хто навчається, такої зорової інформації, яка може бути отримана в реальній бойовій обстановці спостереженням за діями своїх військ, військами противника та за результатами 
вогневого ураження. До такої інформації слід віднести:

- положення військ (характер дій, накреслення переднього краю, розміщення опорних пунктів, вогневих засобів, ступінь інженерного обладнання);

- розвідувальні ознаки (фізичні та оперативнотактичні);

- рух окремих та групових об'єктів, політ ракет, снарядів, мін, тощо;

- результати дії засобів ураження (руйнування споруд, ураження (пошкодження, припинення руху) об'єктів, створення осередків пожеж);

- імітацію наземних, повітряних розривів, рикошетів, характерних при застосуванні основних типів снарядів, в тому числі й спеціальних (димових, запалювальних, освітлювальних).

Моделюванням бойових дій 3 відображенням очікуваних результатів на основі прийнятого рішення це наочне відображення змін в поточній обстановці, які адекватні діям тих, хто навчається, і $\epsilon$ найбільш складним етапом в процесі моделювання візуального зображення бойової обстановки. Його складність полягає в необхідності наочного відображення змін в поточній обстановці за принципом «воєнної комп’ютерної гри» (ВКГ). ВКГ повинна забезпечувати імітацію процесів бойових дій протидіючих сторін шляхом створення віртуального середовища, на основі якого ті, що навчаються, мають змогу оцінювати обстановку, приймати рішення, віддавати накази та розпорядження, контролювати хід їх виконання. Вирішити це питання можливо за умов розробки у складі СПМЗ набору розвинутих моделей поведінки супротивника та своїх військ в залежності від дій того чи іншого учасника «віртуального бою».

Візуальне відображення бойової обстановки за допомогою ВПС дозволить наблизити процес навчання до реальних умов. Найбільш складним видом СПМЗ стануть програми, які підтримують функціонування комп’ютерної мережі віртуального середовища для імітації поля бою та циркуляцію інформації в ній.

\section{Динамічна платформа з системою управління}

Динамічні платформи бувають 3 електромеханічним і гідравлічним приводом. Ряд відомих виробників, наприклад - Krauss Maffei Wegmann (Німеччина), Lockheed Martin (США), Thales Training \& Simulation (Франція), в своїх тренажерах використовують платформи 3 гідравлічним приводом. По розміщенню багато 3 них являються дворівневими:

- на першому поверсі - динамічний привід;

- на другому - кабіна члена екіпажу.

Такий підхід пояснюється перш за все спадковістю i уніфікацією 3 авіаційними тренажерами, що випускалися раніше.

Українські розробники тренажерів (КП ХКБМ (м. Харків), ТзОВ МАРКЕТ-МАТС (м. Львів) та ін.) застосовують в своїх платформах електромеханічний привід. До його переваг відносно гідравлічного привода можна віднести:

- невеликі габарити;

- більш високий коефіцієнт корисної дії;

- більшу безпечність і надійність.

Динамічна платформа як правило універсальна i допускає встановлення любої кабіни 3 робочим місцем члена екіпажу, що не виходить за задані вагові і габаритні показники.

\section{Програмне забезпечення з математичними моделями}

Програмне забезпечення повинно включати в себе весь спектр математичних моделей, починаючи від найпростіших логічних моделей і закінчуючи складними моделями двигуна i руху об'єкта. Математичні моделі, які застосовуються в сучасних тренажерах, позволяють 3 високою ступінню достовірності відтворити різноманітні процеси, такі як пуск двигуна, рух техніки по різноманітних типах грунту, замір дальності, робота стабілізатора озброєння, механізму заряджання, балістичного обчислювача, ураження цілей боєприпасами 3 різноманітною балістикою та ін. Частина математичних моделей суміщена 3 системою візуалізації і проводить розрахунок зіткнень 3 перешкодами.

\section{Засоби відпрацювання взаємодії всередині екіпажу бойової машини}

До засобів відпрацювання взаємодії всередині екіпажу бойової машини будуть відноситись тренажери екіпажів, які створюються шляхом об'єднання засобів індивідуальної бойової підготовки (тренажерів членів екіпажу) в єдину мережу. На віртуальному полігоні такий екіпаж буде представлено єдиним об'єктом (будь то пускова установка, самохідна артилерійська установка, транспортно-заряджаюча машина броньована чи інша бойова машина) - тренажером екіпажу, який необхідно підготувати.

Тренажер такого типу дозволяє підвищити злагодженість роботи екіпажу в умовах, що відповідають бойовим, відпрацювати взаємодію як всередині екіпажу, так і з старшим командиром, який в цьому випадку являється інструктором.

На віртуальному полігоні екіпаж повинен мати можливість вести дуельний бій як 3 віртуальним противником, так і з іншим тренажером екіпажу бойової машини, який завантажений в цей же віртуальний полігон, що $є$ кроком до наступної 
сходинки засобів відпрацювання взаємодії тренажерам відпрацювання взаємодії всередині підрозділів і між підрозділами.

\section{Засоби відпрацювання тактичної взаємодії екіпажів бойових машин в складі підрозділу і відпрацювання тактичної взаємодії підрозділів}

Тренажери екіпажів бойових машин необхідно об'єднати в мережу для ведення сумісних дій на єдиному віртуальному полігоні, будь то відпрацювання тактичних прийомів, відпрацювання водіння в колоні, відпрацювання дій на віртуальній місцевості, яка відповідає місцевості бойових дій, які передбачаються, або навчань на реальній техніці. Ієрархія такої мережі тренажерів буде обмежена фінансовими можливостями замовника (наприклад тренажер артилерійського (ракетного і ін.) взводу, батареї, дивізіону).

\section{Засоби відпрацювання оперативно-стратегічної взасмодії 3 іншими родами військ}

Цей рівень тренажерних засобів призначений для старшого командного складу, штабних працівників і т. ін., і повинен бути аналогом комп'ютерних ігор - стратегій реального часу.

Основою для вказаних засобів стратегічної взаємодії з іншими родами військ будуть цифрові карти реальної місцевості 3 базою даних, яка включає інформацію про економічний і політичний потенціал даного регіону.

Для організації навчання командного складу в країнах НАТО створені спеціальні комп’ютерні центри, які дозволяють проводити штабні навчання як всередині країни, так і міжнародні. Одним із суттєвих недоліків такого навчання $€$ відсутність суб'єктивних факторів пов'язаних 3 участю особового складу, які впливають на хід виконання операцій.

Для усунення вказаного недоліку доцільно залучати рядовий і молодший командний склад 3 підключенням розглянутих вище тренажерних засобів. Швидше за все, в майбутньому розвиток комп'ютерних засобів навчання піде якраз по шляху об’єднання тренажерів різноманітних рівнів в єдину ієрархічну структуру.

\section{Комп'ютерно-оріснтоване методичне забезпечення}

Основою комп'ютерно-орієнтованого методичного забезпечення повинен стати апаратнопрограмний комплекс - програмно-апаратне рішення, що забезпечує генерацію єдиної фоноцільової обстановки і взаємодію всіх тренажерних комплексів в ній.

У комплексі можливе створення комп'ютерних тренажерів будь-яких систем:

- ракетних, артилерійських i розвідувальних комплексів;

- номерів бойових розрахунків ланок управління;

- операторів бронетанкових засобів;

- механіків-водіїв, і т.д.

Апаратно-програмний комплекс повинен мати ряд ознак, ключовими з яких є:

1. Реалізація принципу «один тренажер - один комп'ютер», що збільшує надійність і зменшує вартість комплексу в цілому.

2. Можливість віртуалізації дій будь-якого члена екіпажу модельованого зразка бойової техніки, що дозволяє тренуватися при неповному складі розрахунку.

3. Орієнтація на промислові стандарти при взаємодії тренажерних комплексів шляхом використання стандартних протоколів взаємодії військових тренажерних систем.

Структура апаратно-програмного комплексу повинна бути наступною:

- комплекс математичного моделювання;

- система візуалізаціі;

- система введення-виведення.

Програмно комлекс повинен складатися 3 наступних модулів:

- модуль інструктора;

- модуль оператора (операторів);

- конструктор тактичної обстановки.

Створені в рамках комплексу комп'ютерні тренажери повинні забезпечувати:

1. На етапі підготовки завдання в модулі інструктора і конструкторі тактичної обстановки:

- завдання вправи 3 курсу стрільби або іншої регламентуючої документації;

- завдання погодних умов (дощ, сніг, вітер, гроза і т.д.);

- завдання балістичних параметрів (температура зарядів, щільність повітря і т.д.);

- завдання виникаючих несправностей i перешкод в роботі конкретного озброєння i устаткування;

- завдання алгоритмів поведінки сусідніх сил $\mathrm{i}$ засобів союзників i супротивника (наземних, повітряних, морських), а також цивільного населення;

- вибір озброєння, виду його форми і забарвлення залежно від країни і місця ведення бойових дій, антропометричних характеристик для живої сили супротивника на основі бази даних сил і т.д.

2. На етапі виконання завдання у всіх модулях: 
- вивчення інтерактивної мультимедійної енциклопедії по відповідному зразку озброєння;

- підготовку зброї до стрільби, заряджання i розряджання відповідно до алгоритму бойової роботи;

- стрільбу по цілях (живій силі, бронетехніці, авіації, диверсантах і т.д.) відповідно до технічної моделі конкретного зразка озброєння і врахуванням впливу на нього зовнішніх умов;

- відтворення фотореалістичної заданої фоноцільової обстановки;

- роботу декількох навчаємих в єдиній фоноцільовій обстановці, у тому числі і видалено (по локальній мережі або Internet), зокрема 3 різного озброєння;

- відтворення динамічних характеристик засобу переміщення і впливу їх на оператора 3 використанням динамічної платформи;

- голосовий зв'язок всіх, хто навчається (при моделюванні засобів радіозв'язку), а також інструктора і навчаємих;

- відтворення фонової обстановки навколишній бій, звуки пострілів, розривів і т.д.;

- спостереження за процесом виконання завдання 3 місця інструктора за допомогою встановлюваних в довільних місцях фоно-цільової обстановки віртуальних камер;

- припинення або повну зупинку виконання завдання у будь-який момент 3 місця інструктора i т.д.

3. Після виконання завдання в модулі інструктора і конструкторі тактичної обстановки:

- виставляння оцінки в автоматичному режимі відповідно до нормативів, статутів, настанов, курсів стрільби і інших нормативних документів;

- запис ходу виконання завдання в базу даних;

- перегляд ходу виконання завдання 3 бази даних в реальному, прискореному або сповільненому масштабі часу з будь-якого моменту для аналізу дій тих, хто навчається;

- друк протоколів виконання завдання для атестації тих, хто навчається з бази даних;

- статистичний аналіз по кожному 3 тих, хто навчається, або по групі навчаємих;

- порівняльний аналіз різних тренувань між собою і т.д.

\section{Висновки}

Запропоновані принципи побудови перспективних НТ3 для підготовки екіпажів бойових машин, підрозділів (частин, з'єднань), ланок управління $\mathrm{PBiA}$ вказують на те, що об'єднання тренажних засобів, імітаторів стрільби і ураження, класів стрільби і управління вогнем, тренажерів операторів-навідників, механіків-водіїв та інших засобів, які забезпечують підготовку певних категорій військовослужбовців PBiA за єдиним задумом i оперативно-тактичним фоном приведе до створення ТМС РВiА, яка буде мати ієрархічну будову у відповідності до штатної структури РВіА СВ.

Основою технічного i методичного забезпечення підготовки частин і підрозділів, органів управління РВіА будуть спеціалізовані класи, об'єднані інтегрованими автоматизованими навчальними курсами і програмами та обладнані комп'ютерними процедурними i комплексними тренажерами, які забезпечать проведення занять як індивідуально, так і в складі екіпажу і підрозділу.

Тренажерне устаткування повинно одночасно удосконалюватися за наступними напрямками:

- розробка тренажерів i електронних навчальних систем (ЕНС) для конкретних видів озброєння і військової техніки РВіА (це тренажери індивідуальної підготовки тих, хто навчається). ЕНС мають набір програм з автоматизованими учбовими курсами, вони $є$ інтегральним засобом навчання i дозволяють показ слайдів, плакатів, мультиплікації і т.п. Разом 3 функцією подачі учбового матеріалу, комп'ютерна частина підручника виконує функції контролю вивчення учбового матеріалу 3 виставлянням оцінок, проведенням аналізу і обліком результатів навчання. У інформаційно-довідкова система, автоматизовані учбові курси. Це дозволяє створити необхідне інформаційне середовище. Простота тиражування і використання ЕНС дозволяє ефективно застосовувати їх в системі підготовки РВіА;

- формування мережі тренажерів для відпрацювання бойових завдань типу дуельних i ряду інших ситуацій як індивідуальних, так i y складі розрахунку. Окрім однотипних сценаріїв поведінки програмно-реалізованого супротивника в навчанні повинні бути змагальні (дуельні) методи навчання. Для цього необхідно формувати локальні обчислювальні мережі тренажерів, що замикаються на центральну ЕОМ із спеціальним програмним забезпеченням, що імітує поведінку супротивника, місцевість, погодні умови i т. п. Дана мережа повинна охоплювати всіх тих, хто навчається. У повсякденній діяльності $\mathrm{PBiA}$ повинні бути в процесі безперервних тренувань в штучному середовищі, що імітує поле бою або інші умови, набувати досвіду, накопиченого в результаті реальних дій. Ця мережа повинна розглядатися як універсальна військово-технічна система;

- розробка тренажерів для вдосконалення управління РВіА різних тактичних рівнів (взвод, батарея, дивізіон), створення автоматизованих 
систем моделювання бойових дій в ТМС для реалізації комп'ютерних форм підготовки РВіА;

- забезпечення подібності штучного середовища (середовища бойової діяльності, імітованого на тренажері) реальному середовищу.

Склад та структура ТМК для кожної окремо взятої частини РВіА визначатиметься шляхом доповнення базової комплектації відповідними ТМ та СПМЗ з урахуванням призначення частини, покладених на неї завдань, іiі організаційно-штатної структури, умов розташування та експлуатації військової техніки та озброєння.

\section{Список літератури}

1. Аналіз сучасного стану та обгрунтування напрямків розвитку навчально-тренувальних засобів ракетних військ $i$ артилерії: Звіт про НДР (заключний). Науковий иентр Сухопутних військ. - інв. № 01-08-НОВ. Львів, 2008. -55 c.
2. Опис обрису, структури та вимог за призначенням до уніфікованого тренажерномоделювального комплексу та його складових: Звіт про НДР (проміжний). Науковий иентр артилерії. - інв. № 3565. - Суми, 2002. - 181c.

3. Арфеев В.Ю Использование компьютерной техники для обучения войск (Зарубежный опыт) / Арфеев В.Ю, Жадоби А.П., Петровський В.Н. // Военная мисль, 1997. - № 1. - С. 74-78.

4. Сайфетдинов Х.И. Реформирование боевой подготовки: компьютерные формы обучения / Х.И. Сайфетдинов // Военная мысль, 1998. - №36. C. 12-16, 77-81.

5. Шмаль В.С. Військова топографія: Підручник / Шмаль В.С. - К.: 1998. -232 c.

Надійшла до редакиії 4.09.2009 p.

Рецензент: доктор технічних наук, старший науковий співробітник А.М. Зубков, Академія сухопутних військ, Львів.

\title{
ПРИНЦИПЫ ПОСТРОЕНИЯ ПЕРСПЕКТИВНЫХ УЧЕБНО-ТРЕНИРОВОЧНЫХ СРЕДСТВ ДЛЯ ПОДГОТОВКИ ЭКИПАЖЕЙ БОЕВЫХ МАШИН, ПОДРАЗДЕЛЕНИЙ (ЧАСТЕЙ, СОЕДИНЕНИЙ), ЗВЕНЬЕВ УПРАВЛЕНИЯ РАКЕТНЫХ ВОЙСЬК И АРТИЛЛЕРИИ СУХОПУТНЫХ ВОЙСК
}

\author{
Я.В. Красник, О.В. Рымар, С.А. Мартыненко
}

Решение проблемы низкой эффективности учебно-тренировочных средств ракетных войск и артиллерии Сухопутных войск требует создания эффективных учебно-тренировочных средств для подготовки экипажей боевых матин, подразделений (частей, соединений), звеньев управления ракетных войськ и артиллерии, которые в последуюшем будут объединены в тренажно-моделирующие комплексы и системы. Предложенные в статье принципы построения учебно-тренировочных средств являют собой ряд конкретных предложений относительно создания перспективных учебно-тренировочных средств для подготовки экипажей боевых машин, подразделений (частей, соединений), звеньев управления ракетных войськ и артиллерии Сухопутных войск. Результаты могут быть использованы в интересах ракетных войськ и артиллерии Сухопутных войск в ходе выполнения опытных и опытноконструкторских работ относительно отработки технических заданий для модернизации и создания учебнотренировочных средств, планирования их использования в учебном прочессе, а такэе для создания перспективных учебно-тренировочных средств других родов войск Сухопутных войск.

Ключевые слова: ракетные войска и артиллерия, учебно-тренировочные средства, тренажно-моделируюший комплекс, тренажно-моделирующая система, тренажер

\section{PRINCIPLES OF PROSPEROUS EDUCATIONAL AND TRAINING FACILITIES CREATION FOR THE TRAINING OF FIGHTING VEHICLES CREWS, SUB-UNITS (UNITS AND LARGE UNITS) AND BRANCHES OF THE MISSILE FORCES AND ARTILLERY COMMAND OF THE ARMY}

\author{
Krasnyk Y. V., Rymar O .V., Martynenko S.A.
}

Solution to the problem of low efficiency of educational and training facilities of the Missile Forces and Artillery of the Army requires the creation of the effective educational and training facilities for the training of fighting vehicles crews, sub-units (units and large units), branches of the Missile Forces and Artillery of the Army command which will be jointed into training and simulation complexes and systems afterwards. Suggested in the article principles of the educational and training facilities creation represent themselves as a concrete suggestions according the prosperous educational and training facilities creation for the training of fighting vehicles crews, sub-units (units and large units) and branches of the Missile Forces and Artillery command of the Army. The results may be used in the interests of the Missile Forces and Artillery of the Army during the conduct of research works on refining the technical tasks for the modernization and creation of the educational and training facilities, planning their utilization in the educational process and creation of the prosperous educational and training facilities of other arms of the Army either.

Keywords: Missile Forces and Artillery, educational and training facilities, training and simulation complex, training and simulation system, trainer. 